\title{
PENGENDALIAN RESIKO BAHAYA NAIK TURUN TANGGA DENGAN MEMASANG ANTI TOE SLIP DAN PENERAPAN THREE POINT CONTACT DI AREA SRU PERTAMINA RU IV CILACAP
}

\author{
Didid Q Muhlis $^{1 *}$, Khotibul Umam², Andy Tirta ${ }^{3}$ \\ ${ }^{1}$ Program Pascasarjana Manajemen Inovasi, Universitas Teknologi Sumbawa \\ ${ }^{2}$ Program Studi Bioteknologi, Universitas Teknologi Sumbawa \\ ${ }^{3}$ Program Studi Metalurgi, Universitas Teknologi Sumbawa \\ Coresponding author : khotibul.umam@uts.ac.id, andy.tirta@uts.ac.id
}

\begin{tabular}{|c|c|}
\hline & Abstrak \\
\hline $\begin{array}{l}\text { Diterima : } \\
\text { Bulan Januari } \\
2021\end{array}$ & $\begin{array}{l}\text { Resiko bahaya kejadian kerja yang umumnya terjadi pada area kilang RFCC yakni } \\
\text { kejadian terjatuh saat naik atau turun tangga. Biasanya hal ini terjadi karena konsep three } \\
\text { point contact sering diabaikan, yakni penggunaan tangga dengan aman dengan selalu } \\
\text { mempertahankan tiga titik kontak disetiap waktu. Selain itu pula diterapkan inovasi anti- } \\
\text { toe slip sebagai pengaman ganda dalam bekerja saat naik turun tangga. Tujuan dari } \\
\text { penelitian ini untuk mengetahui pengaruh penggunaan anti toe slip dan metode three- }\end{array}$ \\
\hline $\begin{array}{l}\text { Diterbitkan: } \\
\text { Bulan Februari } \\
2021\end{array}$ & $\begin{array}{l}\text { point contact dalam naik turun tangga dan tingkat kepahaman pekerja dalam edukasi } \\
\text { mengenai resiko bahaya di area Kilang RFCC Pertamina RU IV Cilacap. Untuk } \\
\text { mendapatkan data komprehensif dalam penelitian, digunakan metode analisis kualitatif } \\
\text { deskriptif, dimana penjabaran data dari hasil observasi lapangan yang berupa wawancara } \\
\text { dan kuesioner dengan pertanyaan yang relevan. Selanjutnya data di analisis dan disajikan }\end{array}$ \\
\hline $\begin{array}{l}\text { Keyword : } \\
\text { resiko bahaya, } \\
\text { anti toe slip, three } \\
\text { point contact }\end{array}$ & $\begin{array}{l}\text { dalam bentuk diagam atau histogram. Penelitian ini menunjukkan bahwa penggunaan anti } \\
\text { toe slip dan penerapan three point contact sangat penting untuk dilakukan karena dpat } \\
\text { meminimalisir terjadinya kejadian terjatuh saat naik turun tangga selama pekerjaan. } \\
\text { Sebanyak } 64 \% \text { dan } 24 \% \text { responden menyatakan bahwa penggunaan metode ini sangat } \\
\text { aman untuk bekerja diketinggian karena adanya perlengkapan safety yang mencegah licin } \\
\text { saat naik tangga. Sedangkan konsep thee point contact dapat membantu pekerja untuk } \\
\text { terus focus dalam memposisikan tangan dan kakai saat berada di tangga sehingga kejadian } \\
\text { terjatuh dapat dihindari. Pemberian edukasi tentang penggunaan anti toe slip dan three } \\
\text { point contact menjadi faktor yang juga menentukan tingkat kemanan dalam bekerja di } \\
\text { ketinggian saat menggunakan tangga. Dari } 50 \text { responden yang diobservasi, sebanyak } 94 \% \\
\text { sangat setuju bahwa edukasi menjadikan para pekerja menjadi lebih paham dan aware } \\
\text { dengan perlengkapan keselamatan yang harus digunakan dan tentunya mencegah dari } \\
\text { resiko terjatuh saat naik tangga. }\end{array}$ \\
\hline
\end{tabular}

\section{PENDAHULUAN}

Industri Minyak dan Gas Bumi merupakan sektor yang penting dalam pembangunan nasional. Pemenuhan kebutuhan energi dan bahan baku industri akan selalu menyertakan sektor migas baik di dalam negri maupun luar negri (LM FEUI, 2012). Dalam praktik pelaksanaannya, industri migas memiliki tingkat resiko tinggi yang dapat disebabkan oleh banyak faktor. Menurut Suma'mur (2014) secara garis besar kejadian kecelakaan kerja disebabkan oleh dua faktor, yaitu tindakan manusia yang tidak memenuhi keselamatan kerja (unsafe act) dan keadaankeadaan lingkungan yang tidak aman (unsafe condition). Kecelakaan yang disebabkan akibat tindakan dari pekerja (human resources) terhadap persyaratan keselamatan dan kesehatan kerja dapat berakibat fatal sehingga menimbulkan bencana yang berdampak sangat serius (Badan Pengatur Hilir Minyak dan Gas Bumi, 2019).
Pada tahun 2016, kecelakaan kerja fatal di kegiatan usaha migas mencapai 8 kejadian dan mengalami peningkatan 6 kejadian di tahun 2018 (Laporan Kinerja Direktorat Jendral MIGAS, 2018). Menurut laporan Occupational Safety and Health Administration (OSHA) dan National Safety Council (NSC), bentuk kecelakaan memiliki banyak jenis, seperti terpeleset, tersandung, dan terjatuh yang mengakibatkan lebih dari 300.000 pekerja mengalami cedera setiap tahunnya atau rata-rata satu pekerja mengalami cedera setiap dua menitnya. Dampak yang ditimbulkan tidak hanya mengakibatkan luka ringan, cedera serius/ fatal hingga kematian bagi pekerja, namun juga mengakibatkan kerugian ekonomi bagi perusahaan (Restuputri \& Sari, 2015).

PT Pertamina RU IV Cilacap adalah salah satu dari tujuh kilang pengolahan crude oil menjadi Bahan Bakar Minyak (BBM), Non Bahan Bakar minyak (Non BBM), dan petrokimia di Indonesia dengan kapasitas terbesar yaitu 348.000 barrel/hari. 
Kilang pengolahannya terdiri dari kilang I, kilang II, kilang paraxylene, kilang Sulfur Recovery Unit (SRU), dan kilang Recidual Fluid Catalytic Cracking (RFCC) (Diska, 2020). Setiap proses kerja yang ada di tiap kilang memiliki potensi bahaya baik besar maupun kecil. Dalam hal ini, pekerja memiliki tanggung jawab yang samadengan pihak perusahaan dalam hal pengendalian resiko bahaya yang terjadi. Berbagai upaya yang dilakukan untuk meminimalisir kejadian bahaya di lingkungan perusahaan seperti pelatihan K3, manajemen resiko, seminar kesehatan pekerja dan manajemen kedisiplinan. Manajemen dapat membantu menumbuhkan tanggung jawab pekerja dengan mengubah kebiasaan, menumbuhkan kesadaran dan memberikan pelatihan.

Banyak risiko bahaya lainnya yang bisa ditemui oleh pekerja di tempat kerja. Risiko bahaya yang dihadapi tenaga kerja adalah bahaya kecelakaan kerja serta penyakit akibat kerja yang diakibatkan karena kombinasi dari berbagai faktor seperti tenaga kerja, peralatan kerja dan lingkungan kerja (Sucipto, 2014). Salah satu jenis dari resiko kejadian kerja yang umumnya terjadi pada area kilang RFCC yakni kejadian terjatuh saat naik atau turun tangga. Biasanya hal ini terjadi karena konsepthree point contact sering diabaikan. Three point contact adalah konsep penggunaan tangga dengan aman dengan selalu mempertahankan tiga titik kontak, yakni dua tangan dan satu kaki atau dua kaki dan satu tangan di tangga disetiap waktu. Selain itu, penambahan anti toe slip pada pekerja saat naik turun tangga akan menjadi doble safety di area Kilang RFCC Pertamina RU IV Cilacap.

\section{METODE PENELITIAN}

Sugiyono (2015:15) Penelitian ini termasuk penelitian kualitatif, metode kualitatif adalah metode penelitian yang berlandaskan pada filsafat postpositivisme, digunakan untuk meneliti pada kondisi obyek yang alamiah (sebagai lawannya adalah eksperimen) dimana peneliti adalah sebagai instrumen kunci, pengambilan sampel sumber data dilakukan secara purposive dan snowbal. Penelitian kualitatif mampu melihat fenomena yang lebih mendalam dan dapat berkebang sesuai dengan keadaan yang sedang terjadi dilingkungan sosial masyarakat.

Penelitian ini dilakukan di Lingkungan Kilang Pertamina Refinary Unit IV Cilacap. Sedangkan waktu dilakukannya penelitian selama 2 bulan.

Data yang digunakan dalam penelitian ini terdiri dari data primer yakni berupa data atau hasil wawancara dengan responden yang berasal dari berbagai segmen kerja di lingkungan RSU Pertamina Cilacap. Selain itu, digunakan pula data skunder yang berupa studi literature, hasil survey dan sebagainya.
Teknik pengumpulan data penelitian ini melalui metode wawancara baik wawancara yang sifatnya terstruktur, semiterstrukur dan takterstruktur dimana wawancara yang tidak menggunakan pedoman secara sistematis dan lengkap dalam mengumpulkan data. Sebagai pelengkap dalam menggali melalui wawancara, dilakukan pula observasiuntuk melakukan pengamatan secara langsung ke objek penelitian untuk melihat dari dekat kegiatan yang dilakukan (Riduwan, 2004 : 104). Dalam observasi yang dapat dipotret oleh peneliti bukan hanya manusia tapi, benda poreses dan berbagai fenomena yang terjadi.

Penelitian ini menggunakan bentuk penelitian kualitatif deskriptif dengan mendeskripsikan hasil analisa dalam penegndalian resiko bahaya dengan penerapan aplikasi anti toe slip dan tindakan three point contact saat naik turun tangga. Dalam analisis data, peneliti menggunakan model interaktif, yang meliputi reduksi data (data reduction), penyajian data (data display), dan conclutions drowing/verifiying.

\section{HASIL DAN PEMBAHASAN Penggunaan Tangga Di Area Kerja}

Kecelakan kerja merupakan bagian yang tidak bisa dipisahkan dari suatu aktifitas pekerjaan suatu perusahaan, hanya bisa diminimalisir melalui upaya preventif seperti penerapan K3 secara cermat, penggunaan safety tools dan evaluasi berkala. Menurut Tarwaka (2014), kecelakaan kerja adalah suatu kejadian yang jelas tidak dikehendaki dan sering kali tidak terduga semula yang dapat menimbulkan kerugian baik waktu, harta benda atau properti maupun korban jiwa yang terjadi di dalam suatu proses kerja industri atau yang berkaitan dengannya Dalam penelitian ini, upaya yang coba dianalisa yakni kecelakaan jatuh akibat naik turun tangga pada saat aktifitas kerja di area SRU Pertamina IV Cilacap menggunakan penerapan safety tools anti toe slip dan tindakan three point contact saat naik turun tangga.

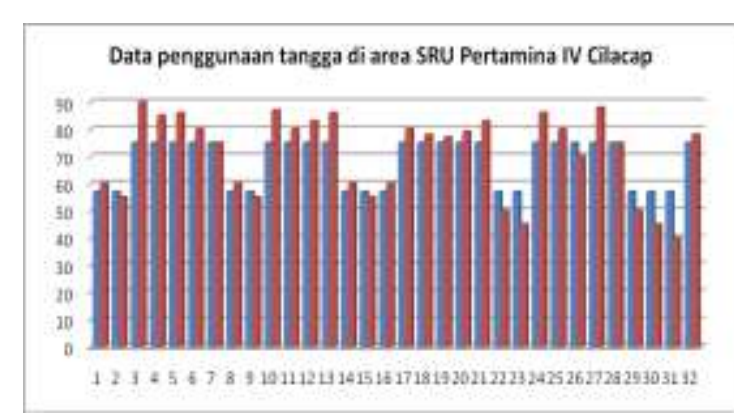

Gambar 1. Penggunaan Tangga Di Area RSU

Evaluasi melalui pengamatan penggunaan tangga selama satu hingga dua bulan pengamatan (gambar 1) menunjukkan hasil yang fluktuatif. Pekerja mengakses tangga yang diposisikan di 
dalam dan di luar sesuai kebutuhan kerja dengan memperhatikan informasi yang diberikan untuk menjaga keamanan saat naik turun angga. Penggunaan anti toe slip dan penerapan three point contact saat menaiki tangga di banyak penelitian terkait safety pekerjaan menunjukkan hasil yang efektif dalam mencegah terjadinya jatuh atau terpeleset. Anti-toe slip digunakan untuk mencegah terpelest atau licinnya pekerja sedangkan three point contact menjaga keseimbangan pekerja saat bekerja di ketinggian dan menaiki tangga, dengan dua tangan dan satu kaki atau dua kaki dan satu tangan di tangga disetiap waktu. Selama pengamatan diperoleh rata rata penggunaan tangga sebanyak 68.3 dan 70,8 orang untuk masing masing penggunaan tangga di dalam dan di luar. Menurut Dewi (2020). Frekuensi pengunaan tangga atau alat lainnya seperti scaffolding sebagaimana rata rata tersebut dalam kategori yang cukup sering, sehingga diperlukan control pengunaan dan tindakan pencegahan pekerja dari penggunaan yang berlebihan yang dapat berakibat kecelakaan. Oleh karena itu, upaya penerapan anti toe slip dan three point contact diperlukan agar dipahami seluruh pekerja untuk menghindari kejadian terjatuh dan terpeleset.

Penggunaan tangga di dalam dan luar sebagaimana ditutnjukkan pada gambar 1, membuktikan bahwa dengan penerapan safety tools secara tepat dan edukasi berkala dapat meningkatakan peluang kecilnya kecelakaan kerja akibat terjatuh atau terpeleset tangga. Hal ini sebagaimana dipaparkan Restuputri dan Sari (2015) bahwa perlindungan diri dari kecelakaan kerja dapat dihindari atau diminimlisir dengan penggunaan perlengkapan kerja yang mendukung, dalam konteks pekerjaan di ketinggian seperti penggunaan tangga, maka perlu digunakan sepatu anti selip, helm, rompi, dan penggunaan tali pengaman.

\section{Faktor yang Mempengaruhi Kejadian Terjatuh}

Faktor-faktor yang mempengaruhi terjadinya kejadian terpeleset dijabarkan sebagaimana hasil yang diperoleh pada gambar 2 dari 50 responden yang diinterview tentang penyebab terjatuh atau terpeleset, sebanyak $42 \%$ dikarenakan tangga licin. Faktor pegangan tangan yang kurang kokoh saat naik dan turun tangga sebanyak $20 \%$ diyakini responden sebagai salah satu yang menyumbang kejadian terjatuh yang cukup sering.

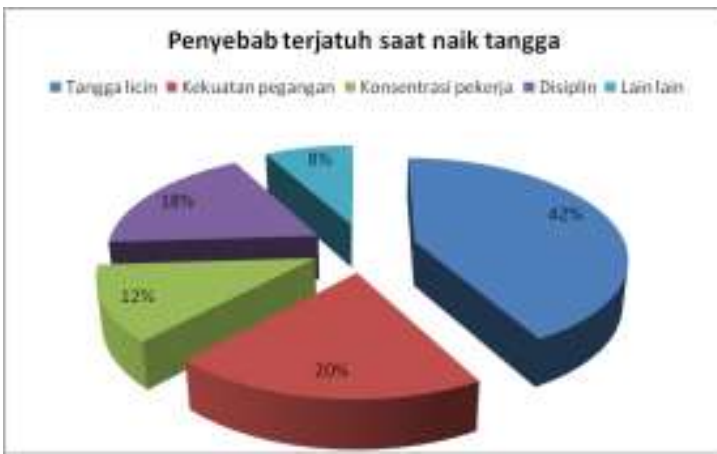

Gambar 2. Faktor-faktor Penyebab Terjadinya kecelakaan Saat Naik Turun Tangga

Biasanya, dalam bekerja diketinggiaan selalu ada SOP khusus yang harus diikuti, salah satunya teknik three point contact (Suhardi, 2008). Teknik berpegangan pada tangga dengan dua tangan dan satu kaki atau satu tangan dan dua kaki menjadi penting sebagai teknik dasar untuk menghindari kecelakaan. Kekokohan pegangan dan kaki dapat berakibat fatal akibat tidak menerapkan three point contact secara cermat. Sedangkan faktor lainnya dipengaruhi pula oleh kedisiplinan pekerja sebesar $18 \%$ saat menaiki atau turun tangga. Kedisiplinan ini terkait dengan banyak hal seperti terburu buru, ingin cepat selesai, sehingga mengakibatkan pekerja tidak mengikuti prosedur yang tepat. Disiplin dalam mengikuti prosedur kerja penting untuk menjaga keselamatan di area kerja (Nopiyanti, 2020). Factor lain yang berpengaruh yaitu konsentrasi pekerja sebesar $12 \%$ dan lain lainnya sebesar $8 \%$.

\section{Pengaruh Antitoe Slip dan Penerapan Three Point Contact}

Penelitian ini selanjutnya menganalisa dampak dari penggunaan metode untuk meminimalisir terjadinya kecelakaan kerja saat naik turun tangga dengan penerapan toe slip dan three contact point. Hasil observasi ke 50 responden dengan penyebaran angket dengan indicator sangat aman, aman, biasa saja dan tidak berdampak ditampilkan dalam Gambar 3.

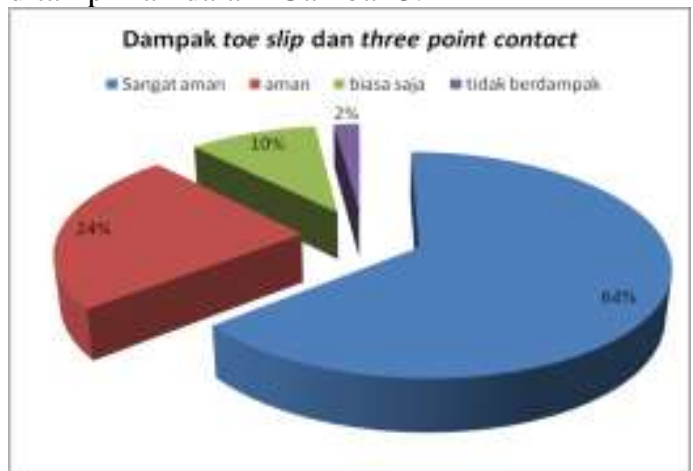

Gambar 3. Faktor-faktor Penyebab Terjadinya kecelakaan Saat Naik Turun Tangga 
Berdasarkan hasil uji heterokedasitas menggunakan SPSS diperoleh hasil signifikasi variabel X1, X2, X3 lebih besar dari 0,05. Maka dapat disimpulkan bahwa data penelitian tidak terjadi masalah heterokedasitas.

Pekerja merasa sangat aman dengan penerapan toe slip dan three point contact saat bekerja di ketinggian mencapai $64 \%$, sedangkan yang menjawab tidak berdampak hanya sebesar $2 \%$ saja. Hal ini, secara umum menunjukkan bahwa pengaruh penerapan safety dalam mencegah terjadinya kejadian terjatuh atau terpeleset saat naik dan turun tangga memiliki dmpak yang signifikan. Saat merasa aman, produktifitas kerja akan meningkat seiring pula dengan kedisiplinan kerja yang memperhatikan prosedur keamnanan (Irwansyah, dkk., 2017). Penelitian ini relevan dengan hasil yang diperoleh dari Ponda dan Fatma (2019) yang menunjukkan bahwa pengendalian bahaya dalm kerja dapat mengurangi kecelakaan kerja (non fatality dannon LTI) dan mengurangi penyakit akibat pekerjaan. Toe slip dan three point contact merupakan metode yang digunakan dalam pencegahan kecelakaan, sehingga kecelakaan akibat human eror dan tools yang kurang memadai dapat dihindari.

\section{Peran Edukasi tentang Bahaya Terjatuh}

Selain perlengkapan yang memadai dalam perlindungan kerja dan metode yang tepat dalam meminimalisir kejadian terjatuh saat naik dan turun tangga, maka perlu dilakukan pula transfer pengetahuan terkait bahaya dalam kerja untuk mengedukasi para pekerja khususnya dalam pekerjaan yang berada diketinggian seperti saat naik dan turun tangga.

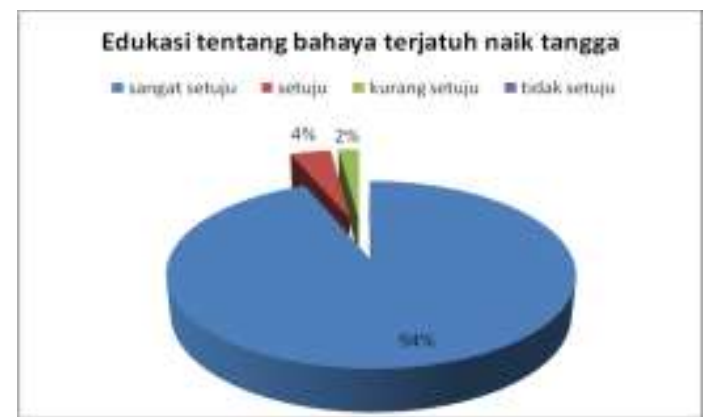

Gambar 3. Edukasi tentang Bahaya Terjatuh Naik Tangga

Analisa data responden yang diperoleh dari pengamatan edukasi tentang bahaya terjatuh saat naik turun tangga menunjukkan tingginya tingkat pemhaman pekerja dalam mengetahui resiko bahaya.Sebanyak $94 \%$ responden sangat setuju dengan adanya edukasi, meskipun $2 \%$ responden menyatakan tidak setuju dikarenakan factor tidak punya waktu dan mungkin ada potensi responden sudah memahami hal tersebut.Namun, tingginya keingintahuan responden menjadi dasar bahwa menjaga keselmatan dalam pekerjaan dengan memperoleh informasi yang tepat merupakan hal yang sangat penting untuk diberikan.Perusahaan dan manajemennya memiliki kewajiban untuk mengedukasi pekerja sebelum melakukan jenis aktifitas kerja yang memiliko potensi kecelakaan tinggi. Bekerja dengan tangga pada ketinggian biasanya memerlukan tools khusus (Dewi, 2020).

\section{PENUTUP \\ Kesimpulan}

Berdasarkan penelitian yang telah dilakukan, maka dapat disimpulkn bahwa:

1. Penggunaan anti toe slip dan penerapan three point contact sangat penting untuk dilakukan karena dpat meminimalisisr terjadinya kejadian terjatuh saat naik turun tangga selama pekerjaan. Sebanyak $64 \%$ dan $24 \%$ responden menyatakan bahwa penggunaan metode ini sangat aman untuk bekerja diketinggian karena adanya perlengkapan safety yang mencegah licin saat naik tangga. Sedangkan konsep thee point contact dapat membantu pekerja untuk terus focus dalam memposisikan tangan dan kakai saat berada di Tangga sehingga kejadian terjatuh dapat dihindari.

2. Pemberian edukasi tentang penggunaan anti toe slip dan three point contact menjadi faktir yang juga menentukan tingkat kemanan dalam bekerja di ketinggian saat menggunakan tangga. Dari 50 responden yang diobservasi, sebanyak 94\% sangat setuju bahwa edukasi menjadikan para pekerja menjadi lebih paham dan aware dengan perlengkapan keselamatan yang harus digunakan dan tentunya mencegah dari resiko terjatuh saat naik tangga.

\section{REFERENSI}

ANSI/ISEA Z358.1-2014. Guardian Emergency Eyewash and Shower Techonology.

Ayu Erinovita, D. (2020). Identifikasi Bahaya, Penilaian, dan Pengendalian Risiko Unit Nht Foc I Pt Pertamina (Persero) Ru Iv Cilacap.

Badan Pengatur Hilir Minyak dan Gas Bumi Fungsi dan Tugas www.bphmigas.go.id

BPJS Ketenagakerjaan 2016. Jumlah kecelakaankerja di Indonesia masih tinggi.www.bpjs.ketenagakerjaan.go.id

Departemen Tenaga Kerja dan Transmigrasi RI. 1980. Permenakertrans No. PER.04/MEN/1980 tentang Syarat-syarat Pemasangan APAR.Jakarta : Departemen Tenaga Kerjadan Transmigrasi RI. 
Depkes RI. 2002. Keputusan Menteri Kesehatan Republik Indonesia No. 1405/MENKES/SK/XI/2002 tentang Persyaratan Kesehatan Lingkungan Kerja Perkantoran dan Industri. Jakarta : Depkes RI.

Dewi, F. S. (2020). Analisis Risiko Keselamatan Kerja Pada Pekerjaan Scaffolding. Jurnal Teknik Ibnu Sina (Jt-Ibsi), 5(01), 1-11.

Irwansyah, M., Lady, L., \& Umiyati, A. (2017). Pengendalian Risiko Kecelakaan Kerja Pada Proses Bongkar Muat Produk Dengan Pendekatan Hira (Studi Kasus Di Pt. Xyz). Jurnal Teknik Industri Untirta.

Kementerian Energi dan Sumber Daya Mineral.2018. Data Kecelakaan Kerja Kegiatan

Hulu.http://statistik.migas.esdm.go.id/inde x.php?r=dataKecelakaanKerjaHulu/index. Kementerian Energi dan Sumber Daya Mineral. (29 April 2018)

LM FEUI. 2012. Analisis Industri Minyak Dan Gas Di Indonesia. (16 April 2018).

Nopiyanti, E., \& Muttaqin, A. (2020).Hubungan Iklim Keselamatan Dengan Budaya K3 Di Proyek Citra Tower Kemayoran. Jurnal Bidang Ilmu Kesehatan, 10(1), 1-22.

Osha 3071.(2002). Job Hazard Analysis.Usa: Department Of Labor.

Pemerintah Republik Indonesia.1970. Undangundang No. 1 Tahun 1970 tentang Keselamatan Kerja.Jakarta : Pemerintah RI.

Pemerintah Republik Indonesia. 1979. Peraturan Pemerintah RI No. 11 Tahun 1979 tentang Keselamatan Kerja Pada Pemurnian dan Pengolahan minyak dan Gas Bumi. Jakarta: Pemerintah RI. 2004.Peraturan Pemerintah No. 36 Tahun 2004 tentang Kegiatan Usaha Hilir Minyak dan Gas Bumi.Jakarta : PemerintahRI.

1984.Undang-undang No. 4 Tahun 1984 tentang Ketentuan Pokok Pengelolaan Lingkungan Hidup.Jakarta: Pemerintah RI. 1999.Peraturan Pemerintah No.41 Tahun 1999 tentang Pengendalian Pencemaran Udara.Jakarta : PemerintahRI.

1999.Peraturan Pemerintah RI No. 18 Tahun 1999 tentang Pengelolaan Limbah B3.Jakarta : PemerintahRI.

2001.Peraturan Pemerintah No.82 Tahun 2001 tentang Pengelolaan Kualitas Air dan Pengendalian.Jakarta : PemerintahRI.
2003. Undang-undang No. 13 Tahun 2003 tentang Ketenagakerjaan .Jakarta : PemerintahRI.

2012.Peraturan Pemerintah No.50 Tahun 2012 tentang Penerapan Sistem Manajemen Keselamatan dan Kesehatan Kerja.Jakarta : PemerintahRI.

2015.Peraturan Presiden RI No. 146 Tahun 2015 tentang Pelaksanaan Pembangunan dan Pengembangan Kilang Minyak di dalam Negeri.Jakarta : PemerintahRI

Ponda, H., \& Fatma, N. F. (2019). Identifikasi Bahaya, Penilaian Dan Pengendalian Risiko Keselamatan Dan Kesehatan Kerja (K3) Pada Departemen Foundry Pt. Sicamindo. Heuristic: Jurnal Teknik Industri, 16(2).

Ramli, S. (2010). Sistem Manajemen Keselamatan Dan Kesehatan Kerja Ohsas 18001. Jakarta:Dian Rakyat.

Restuputri, D. P., \& Sari, R. P. D. (2015). Analisis Kecelakaan Kerja Dengan Menggunakan Metode Hazard And Operability Study (Hazop). Jurnal Ilmiah Teknik Industri, 14(1), 24-35.

Standar Nasional Indonesia.2008. Standar Nasional Indonesia ISO/IEC 17025 Tahun 2008.

Suhardi, B. (2008). Perancangan Sistem Kerja Dan Ergonomi Industri. Jakarta: Direktorat Pembinaan Sekolah Menengah Kejuruan.

Sugiyono 2013. Metode penelitian kuantitatif kualitatif dan R\&D. Bandung : afabeta

Sugiyono 2015. Metode penelitian.Bandung : afabeta.

Tarwaka, K. (2014). Kesehatan Kerja Manajemen Dan Implementasi K3 Di Tempat Kerja.

Tim HSE PT. Pertamina. 2013. HSE Plan.Jakarta : PT. Pertamina.

Undang-Undang RI. 1970. Undang-Udang No. 1 tahun 1970 tentang keselamatan kerja.

Undang Undang RI. 2011. Undang-Undang RI No. 24 Tahun 2011 tentang Badan Penyelenggara Jaminan Sosial

ESDM.2017. Laporan

KinerjaDirektoratJenderalMigas20 17.https://migas.esdm.go.id/uploads/ post/LAKIP-2017.pdf 